УДК 351.84:364-053.2]"16/20"(043.2)=111

DOI: 10.34132/pard2021.13.09

\title{
STATE POLICY OF SOCIAL PROTECTION OF CHILDREN AS A SOCIAL SAFETY FACTOR: HISTORICAL EXPERIENCE OF EUROPEAN COUNTRIES FROM THE 17TH TO 21TH CENTURIES
}

Svitlana Surgova, $\mathrm{PhD}$ in Pedagogy, Assistant Professor, Institute of Public Administration, Petro Mohyla Black Sea National University, Mykolaiv, Ukraine.

Olena Faichuk, PhD in Pedagogy, Assistant Professor, Institute of Public Administration, Petro Mohyla Black Sea National University, Mykolaiv, Ukraine.

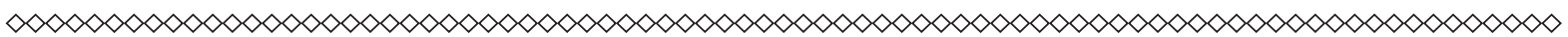

The historical aspect of the development of state social policy of social protection of children in Europe from the 17th to 21th centuries is considered in the article. The purpose of the article is to highlight the peculiarities of the historical development of the state policy of social protection of children in European countries of the 17th to 21th centuries and learning from the experience of social protection of children in the context of Ukraine's European integration. The regulatory framework of the system of social protection of children in Ukraine has been studied. The statistic on different categories of children in need of social protection by the state is analyzed. The structure of the system of social protection of children in Ukraine is considered. The research methodology is based on the principle of priority of universal human values. As part of the tools of the proposed work the theoretical one is the analysis and generalization of scientific sources, educational and methodological publications on the theme and synthesis, as well as comparison and generalization of data. Based on the analysis of materials on the peculiarities of social protection in the UK, Germany, France, Sweden and Norway, it was determined that the social protection of children in Europe is characterized 
by assistance to them in providing conditions for the realization of their rights and freedoms. Equally important is the setting up of various charitable institutions, schools, penal colonies that help children change, as well as the emergence of social services that protect the rights and interests of children. The authors suggest that in the course of the studying the history of the issue of state policy of children's social protection, there is an opportunity for analogies, the implementation of already proven steps on the path of democratization of national social protection policy. The researchers see the prospects for further research in the study of global innovative forms of social protection and support for at-risk children.

Keywords: state policy, social protection of the population, social protection of children, historical development, children with special needs, homeless children, Ombudsman for children, institutional care.

Introduction. All the world's countries have the layers of the society, which require special attention, namely, the children. They comprise a specific social demographic group falling within the ages 0 to 18 years old, which have particular needs, interests and rights, but still devoid of the adequate capacity to assert and defend themselves against the society.

Poor social and economic state of the overwhelming majority of the world population, as well as weakening of typical family functions have aggravated the problems of child social security. Children whose selfworth is being suppressed from the early age, are at risk both physical and psychologically for the rest of their lives. Having been exposed to child trafficking, violence or involved in dangerous jobs, those children, as they grow older, cannot develop themselves as well as actively participate in social life. Presently, the issue of child rights and liberties poses an urgent question in the international relations.

In this context, the issue related to the implementation of our country's policy on the protection of children's rights becomes urgent. As at 01.01.2019, the number of children under the age of 18 in Ukraine amounted to $7,579,703$ people, which amounted to $18.1 \%$ of the total population of the country (according to the State Statistics Service of 
Ukraine, excluding both the temporarily occupied territory and the Autonomous Republic of Crimea and the city of Sevastopol), including $3,903,148$ boys (or $51.5 \%$ of the children's population) and 3,676,555 girls (or $48.5 \%$ of the children's population). Among them 5,030,949 $(66.4 \%)$ children resided in the cities and 2,548,754 (33.6\%) children - in rural areas. The share of children in the total population almost did not change in 2016-2019 and remained in the range of 18.0-18.1\% (Fig. $1)$, although there was a certain increase in the share of children in 20122019 - from $17.5 \%$ to $18.1 \%$ [3].

Figure 1

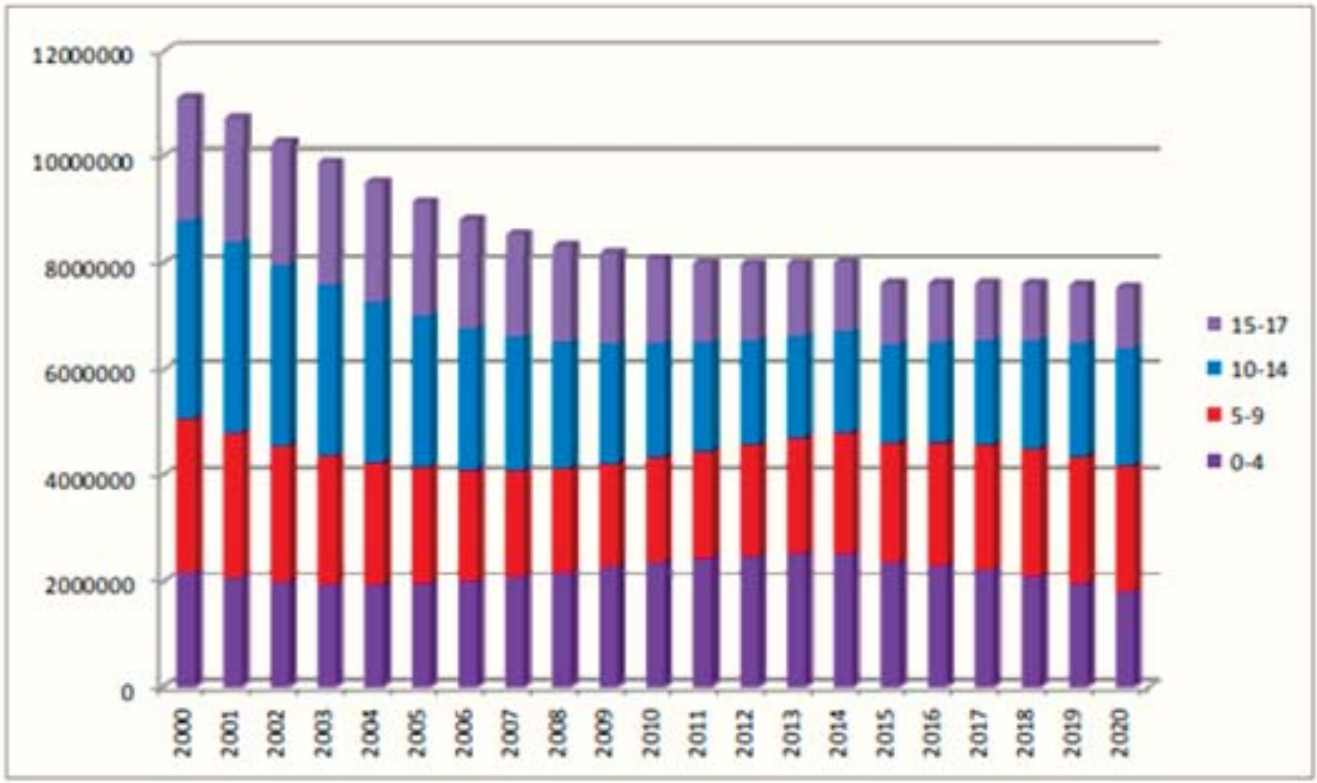

Number of children aged 0-17 by main age groups (Ukraine)

Source: depicted according to the State Statistics Service of Ukraine

Presently, Ukraine is undergoing reforms that envisage, in particular, the introduction and application of a new mechanism of interaction between state executive authorities and local self-government bodies, as well as the creation and maximum approximation to the direct consumer of the public service network in various spheres. A significant problem is the lack of a clear separation of powers between local executive authorities and local self-government bodies, there are numerous cases of duplication of powers. In the vast majority of territorial communities, communal providers of social services have not been created, social work is not 
carried out, cooperation with structural social protection units, children's services of local executive authorities, and NGOs have not been established [7].

It is a proper idea to believe that the state policy, which covers all areas of human life, should be based on the principles and patterns of systemic transformation of society, should be clearly defined by the priorities, which have more details to reveal the social nature of the whole state policy. Nowadays, we all witness that «institutional transformations in Ukraine have not yet led to tangible results in improving the quality of life of the population and stabilizing the social situation in the society. And this cannot but affect the sphere of protection of children's rights. There are many problems that require in-depth study, including the study of the historical experience of the system of protection of children's rights in European countries [2].

Aim and Purpose of the Research. The aim of this article is to highlight the specific features of the historical development of child social security in European countries from 17th to 21th centuries as well as learning from the experience in child social security in the context of European integration of Ukraine.

Research methodology.In order to achieve the goal and perform the tasks of the research, a set of methods of scientific research is applied, namely, theoretical - analysis and generalization of psychological and scientific literature, educational and methodological publications on the theme, synthesis; data comparison and generalization.

Results and Discussion.The ideas on the children's rights are touched on in the works by such outstanding philosophers and educators as J. J. Russo, J. Dewey, J. Korczack, C. Frene. Prominent Russian and Ukrainian teachers have been researching the issue of exercising children's rights in various social institutions, of which there are K. Wentzel, T. Lubenets, J. Zelenkevitch, J. Mamontov, V. Sukhomlinskii.

The problems of children's rights are considered in the works by modern educationalists such as V. Bochariva, T. Vasylkova, J. Vasylkova, L. Volynets, J. Hyppenreiter, N. Zaveriko, A. Kapska, O. Karaman, A. Mudrik, N. Nychkalo, V. Orzhekhovska, O. Starikova, O. Sukhomlinska, S. Kharchenko, Z. Schneckendorff, N. Scherbak among others. The 
works by the scientists mentioned above have prompted us to research the child social security from a historical perspective. It implies that authors from different periods expressed their views on granting rights to children, the trend, which was primarily influenced by historical conditions.Fan, S., Pang, Y. \& Pestieau, P. analyzed the role of pay-as-you-go social security in intra generational risk sharing in an overlapping-generations model with individual heterogeneity [5].

Each national system of child security in Europe has their recognized traditions in terms of its foundation and development.

Childhood research in each society is by essence a multi-faceted and inter-disciplinary phenomenon. Currently the child status is a burning issue. This notion comprises the array of conditions which have been developing within a society for the children to survive and develop. These conditions include the extent of financial well-being, the state of medical care, the development of health care institutions, the system of social education and upbringing, educational capacity of a family, the extent of the state preoccupation with children and, finally, the legal norms which regulate the children's vital rights and interests. The main trend in the social politics in terms of child care is eliminating the negative effect of the social processes and facilitating the conditions for revising the existing and opening the new social institutions which are to satisfy the needs and acting children's interests.

In economically developed countries the issues of the primary concern comprise the appropriate development of a child as well as the irrelationship with adults and enabling child's personal fulfillment.

In Great Britain, in particular, the first legal regulations concerning social problems emerged back in 16th century during the reign of HenryVIII (1531). It proposed to register the individuals who lived off begging and obliged the local authorities to make allowances for the destitute. This marked the first attempt buy the state to transform the uncontrolled charitable activity exercised by the church into the centralized social security system.

In 1607 Queen Elisabeth made a certain codification of the laws and acts in terms of social security, by uniting the single the 'Act for the Relief of the Poor', which had been in force for several centuries. The 
most meaningful contribution to the solution to the problem was made by an English philosopher Robert Owen (1771-1858). At the age of 20 he took charge of the giant enterprise with the severe working conditions for children (most of them started working at the age of 6-7). Robert Owen banned any involvement of children younger than 10 years old in working at the factory and. Moreover, founded a number of institutions for children, which included a school for younger kids - from 1 to 6 years old with a nursery, a kindergarten and a playground, a primary school for kids aged 6 to 10 and an evening school for teenagers working at the enterprise. This way Owen for the first time in history created the pre-school institutions (a nursery and a kindergarten) as well as a primary school for the kids of the factory workers with a comprehensive syllabus. For the kids above 10 and teenagers,by foundingan evening school, he combined studies with productive industrial labor, and opened a worker's club to hold cultural and educational events.

As a result of Owen's long-term activity, in 1819 British Government passed on a law, which limited to a certain extent the child's and women's labor at factories [12, p.148]. From mid-19th century, address relief programs had been provided in England, categorizing kids and youngsters as the priority.

Other European countries, such as Germany, Sweden, Denmark and Finland started implementing social security as a system of legislative, economic and social guarantees till late19th century. In Germany, in particular, O. Bismark issued a number of social laws, which proclaim that the state ensures security in terms of disability, illness or an industrial accident, etc. [4, p. 21]. Certain measures were considered for the youngsters working at factories as well: age limits, ban on juvenile labor in harmful surroundings, etc. [14, p. 37].

Thereinafter, we briefly describe social services for young people in Germany. It should be noted that assistance to children and young people is regulated by the Social Code VIII - social services and tasks. The main goals of assistance to the young in accordance with the Code include: providing opportunities for young people in their individual and social development, preventing discrimination and limiting the interests of young people; advising and supporting parents or persons 
responsible for education of the young; protecting children and young people from risks in order to achieve their well-being; promoting the creation of positive living conditions for young people and their families, in general, the formation of a favorable environment for the protection and development of a family and childhood. Other tasks of assistance to the young in accordance with the Social Code VIII include preventive measures (care for children and the young), protection of children and the young in families and in children's institutions, assistance in litigations and etc. The assistance to the young covers areas of general assistance, including political assistance, and direct assistance. The opportunities for the development of young people and the formation of their skills are a task within the framework of general assistance. Along with this, the assistance to the young also provides for emergency of direct pedagogical and economic assistance if young people and their families experience individual difficulties [11].

Following the major social and political events (bourgeois revolutions in England and France (1 $17^{\text {th }}$ century) there emerges a number of new works highlighting the problematics of child's social security for the first time ever.

John Locke addressed the issue of the social impact of child's labour in the note to the project of the Poor Law in terms of the 'Working Schools' (1696). This way J. Locke proposed to create educational institutions in every community, aimed at children from poor families aged 3 to 15 , which were, by essence, the combination of pre-school institutions and elementary schools.

This approach to upbringing may look imperfect and outdated, but it is worth noting that at that time Locke's proposal in terms of people was extremely progressive. People obtained certain knowledge as well as basic literacy skills. Foundation of kindergartens and schools for children from all walks of life, granting the opportunities to get education not only to the rich but also to the poor, and, moreover, discouraging child labour initiated the emergence of child social security system. It seems strange nowadays. However, if we imagine seeing a 10-year old child working, in it understandable how important Locke's, Frebel's and Owen's implementations were. 
In Sweden, as well as in Germany, granting social care from the state had been mainly focused on labour rights, untilthe 1929 Social Service Law, which incorporated all other spheres in the state's social activity. It clearly defined the social care categories, including orphan kids, disabled children, working youngsters and mothers with a child of tender years $[15$, p. 28].

The specific feature of social care in Sweden is the emergence of the notion of ombudsman. It was in Sweden where the concept of introducing independent monitoring bodies was created to supervise the activity of the state, aimed at the exercising the rights of individuals, so 1809 was when the first ombudsman was appointed. Following Sweden, such institutions were introduced in Finland (1919), Denmark (1955) and Norway (1962).

While ombudsman was primarily the phenomenon typical of Scandinavian countries in the 19th century, from mid-20th century it was introduced in most world countries. Currently, similar institutions with a various degree of competence, legal status and influence, exist in about 100 countries.

As long as children safeguarding has certain specific features, it led to the emergence of an independent entity 'Children's Rights Ombudsman'. The first children's rights ombudsman appeared in Norway in 1981 so as to defend the rights and interests of children at all social layers, as well as to implement the essential changes in child protection policy. According to the recent official accounts (Save the Children Norway) there are presently over 60 children's rights ombudsmen. Only European network comprises 27 countries.

Proceeding with the historical analysis of children's social security in European countries, it has been revealed that France in early 19th century founded special communities for the poor, the homeless and the begging children as well as Houses of Mercy. According to the $1850 \mathrm{Law}$, the state was founding penitentiaries for those of minor age. In particular, a penitentiary in Metre, which combines an orphanage, a prison, a workshop and a military regiment. The tutors were of a particular importance as they performed several functions at a time - they were judges, teachers, masters, officers and parents, this way qualifying as 'specialists in 
shaping child's behavior'. In mid 19th century there appeared institutions for abandoned or sleazy children, orphanages and others.

In Britain, until mid-19th century, working schools were being developed, which were mainly based on the idea of laziness being the grounds for immorality while labour was the best remedy. Therefore, these schools taught workmanship. The disciplinarian function was to be performed by religious groups and charity organizations, focused on religious (instruction), economic (help and involvement in labor) and political (war against rebels) agenda. This is proved by the rules of some parochial charitable institutions in Paris founded at the turn of 18-19th centuries.

This way, the 'isolation' practice was replaced by the 'cellular' charitable system, which comprised orphanages, charity schools, schools for adults, free hospitals, poorhouses, etc. It provided special aid for those in need. Referred to as 'cellular system', it did not support the principle of utter isolation, but was stipulated by the principle of mutual benefit not only by using cheap workforce, but by providing help and expressing sympathy.

The special role in the 'cellular' childcare system was given to institutions for younger children: nurseries and kindergartens, primarily created for the poorest layers of society. Nurseries first appeared in mid1840s in Paris, France, and were initiated by J. Marbeau. In his opinion, nursery was created as a substitute for mothers, being able to protect the youngest ones from the harmful effect in the poor environment. In 1855 the nursery chain accounted for 400 institutions [9].

Another type of charitable institutions was day asylums, which were to provide supervision for those children whose parents were busy working. One of the first asylums was opened in Steingal (Elsas, France) initiated by the local priesr Oberline. Later such institutions caught up in Germany.

Eventually, day asylums, called 'kindergartens spread widely in European countries due to the activity of a German educationalist Friedrick Frebel.

In late 19th century kindergartens appeared in other European countries such as France, Great Britain, Belgium and the Netherlands. A spe- 
cial type of charitable institutions was schools for children with special needs, both physically and mentally disabled.The first institution was founded in Paris way back in 1784, initiated by W. Giuniw and T. Paradi. Later, in mid-1880s Western Europe accounted for 120 institution for visually impaired children. The first institution for deaf and mute children was founded in early 1760s in Paris and Leipzig.At the start of $19^{\text {th }}$ century emerged the special institutions for mentally disabled children. In 1841 in Abendberg (Switzerland) the first school for mentally impaired was opened and in 1842 a similar establishment was founded under the guidance of Berlin deaf and Dumb Institute.

$20^{\text {th }}$ century is the epoch filled with the pedagogical creativity due to the foundation of reformatory pedagogy as well as the formation of a new pedagogic paradigm. The basic principles of the new pedagogical paradigm comprise acknowledging the rights of each individual for development and self-realisation, organizing learning by doing, development of students self-administration, etc.

The analysis of the academic literature enables us to assert that each country has their legislation which regulates children's rights. However, at present considerably more attention is paid to defense of children's rights at international scale, considering the importance of making the state of this sphere as well as the pertinent experience a part of social heritage, and primarily, making it open to those activists and organizations involved in the infringement of human rights.

According to the UNO research, in modern world millions of children are involved in labor, which hinders their development and educational prospects and, eventually, weans them off decent living in the future. Plenty of children are involved in the worst types of child's labor, which harms them both physically and mentally and even may pose a threat to their lives. It all concerns the global child's rights infringement. The future of the mankind depends on the young ones, which implies that protection of child's rights both legally and socially is the constituent part of international law.

Shaping universal legal norms in terms of child's rights protection is related to large-scale measures provided by the UNO from its very onset with a view to create the legal basis for protecting human rights 
and liberties. One of the first results of UNO activity was the Resolution signed by the General Assembly in 1946 in terms of creating a UN Child's Foundation (UNISEF) as a UNO body aimed at providing help to children in Europe following the WWII. What the terms of the Fund's empowerment expired in 1950, by request of the countries of Asia, Africa, Latin America, the General Assembly made are solution to include UNISEF in the UNO structure as a constant entity, with a focus on satisfying the long-term needs of children in developing countries.

The first and the most authoritative document in the sphere of the protection of rights is considered to be the General declaration of $\mathrm{Hu}-$ man Rights issued in 1948. In 1959 UNO adopted the Declaration of the Rights of the Child, which comprised 10 short declarative articles, strategies which appealed for parents, individuals, state bodies, local authorities and the government to acknowledge the liberties mentioned in it and comply with them. Essentially, they were 10 social and legal principles, which had a considerable impact on politics and the activity of governments and individuals worldwide [1]. Modernlifeas well astheworseningstatusofchildren demanded more precise regulations and laws, international agreements concerning defense and provision of children's rights.

Meanwhile, ILO Conventions focused on international effort concerning limiting the use of child labor. One of the critical international legal acts in terms of children's rights protection was the Convention approved on 29 November 1989, which is referred to as the Convention of Children's Rights and comprises the basic modern views on the status of children in the society.

The ratification of the Convention implies that governments are obliged to provide a child with development in a safe and favorable environment, with an access to good-quality education and health care as well as high living standards.

Eventually, irrespective of certain achievements of individual countries in terms of providing for the children's welfare, UNISEF mission has been somewhat transformed: acting in the best interests of children, depending on the needs and avoiding discrimination at all costs. At the same time it is essential to highlight that up until now UNISEF has been 
a major mechanism of international aid provision for kids in poor conditions.

The future of each individual and the mankind as a whole potentially depends on the younger generation, which implies that the provision of children's rights and their legal protection are essentially the main issues of the modern world, which have to be solved by the entire global community.

It seems there is no need to provide any evidence in the light of all mentioned above. One of the proofs states that the vital achievement of the international system of human rights protection is not only acknowledging that 'a child, owing to their physical and mental immaturity, demands special care and protection, including the corresponding legal protection, both before and after their birth', but also recognizing children as independent subjects.

Currently there is a sufficient number of documents (Declaration on social and legal principles in terms of child welfare and protection, in particular when giving children to the care or adoption both nationally and internationally under the date of 2 December 1986; UN Guiding Principles on Crime Prevention among the younger ones (Er-Riyad Guiding Principles) under the date of 14 December 1990; UN Minimal standard requirements on doing right to those under age (Peking Rules) under the date of 29 December 1985; Declaration on Women's Protection in emergencies and military conflicts under the date of 14 December 1974; Vienne Declaration and Agenda (1993); International Declaration on providing child survival, protection and development under the date of 30 September 1990; European Social Charter under the date of 18 October 1961), which are the basic foundations for most countries in the world. It has granted the opportunity to change the approach to the provision of children's rights, to create the opportunities for a better development and providing the necessary protection for children in many countries. However, regardless of an array of achievements in terms of legal regulations, there are more and more new problems in the context of child protection spreading in the world, which prompt new research.

One of such problems is wars. From the very moment of enacting the Convention of Children's Rights, over 80 wars have taken place. It im- 
plies that, on average, there are 4 wars bursting out in the world annually. Additionally, if we consider the long-term effects of most of such conflicts, it makes it obvious, what a huge threat it poses for children's lives as the most unprotected social layer. Besides, the major threat of a war is not only the weapon itself or the cruelty of adults participating in it as opposing parties, but mostly hunger, disease, lack of basic medical service.

Another modern issue is the development of juvenile justice. Initially it used to be the system of institutions and organizations, which exercise justice in terms of offenses committed by the youngsters, which started its development in the USA in 19th century. At present, juvenile justice is a system of normative acts, which regulate the protection of children's rights and crime prevention both nationally and transnationally.

A further major modern problem is access to a considerable volume of data. Unfortunately it weans youngsters off social, mental and spiritual well-being as well as sustainable physical and mental development a child should have. According to the findings of various research, 5080 per cent of all the materials in the Internet is of utterly pornographic nature or is connected with violence or promotion of unhealthy lifestyle, alcohol and drugs consumption, etc.

Thus, children's rights protection, changing their living conditions in a society are of a primary concern of each conscious adult citizen, all public organizations regardless of the sphere they act in. It is a comprehensive principle due to the fast that children, being the future of the society, the state, the country, the planet, are also the future of each living adult who appreciates their life. Therefore, by infringing children's rights today, we doom them for the complications in the future as well as deprive ourselves of support, understanding, respect and stability.

The analysis of historical experience in developing children's social security system in European countries enables Ukraine to hone our own system.

The main categories of children, most in demand of social overprotection from the state in Ukraine are orphans, homeless children, children with disabilities, rape survivors, child trafficking victims, young migrants, children from needy families. The considerable number of those in need has stipulated the necessity to develop a versatile chain of child 
social protection establishments. Its Central Executive Body is Ministry of Social Politics, which supervises:

- Child-care services

- Social service centers for families, children and youngsters

- Child asylums

- Social and psychological rehabilitation centers

- Social support centers for children, families and others.

Figure 2

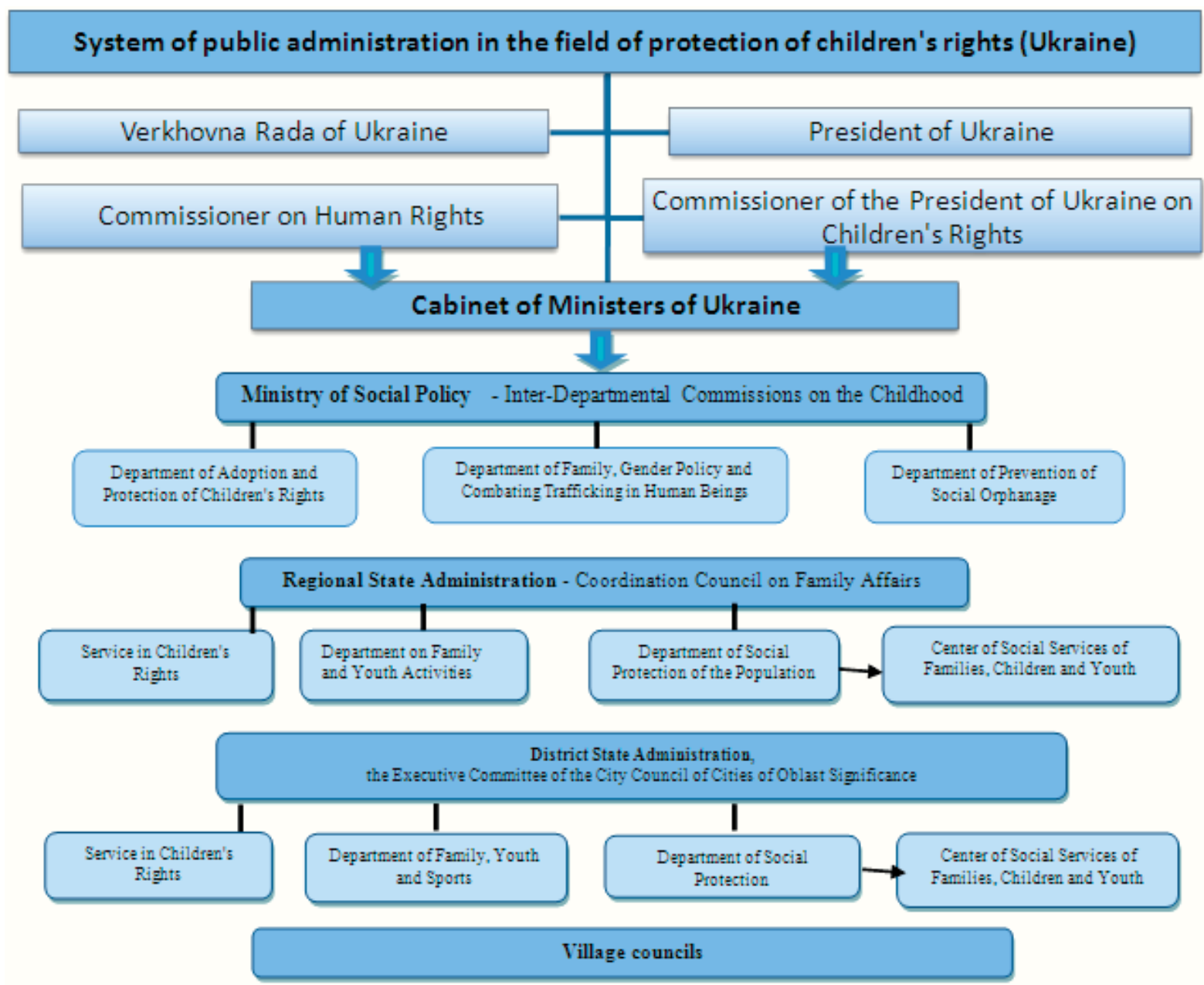

System of public administration in the field of protection of children's rights (Ukraine)

These institutions are designed to deal with the following burning issues: protecting children's rights in all spheres, providing children with appropriate level of education, social and medical care, facilitating their 
physical, psychological, intellectual, metal and moral development; their self-realization in the best interests of the society, providing help to ATO children, etc.

The Ministry of Social Policy, in coordination with people's deputies of Ukraine, is working on bills to improve social protection of orphans and children deprived of parental care, who have a disability and to improve the mechanisms for protecting the housing rights of orphans and children deprived of parental care, the people from the above mentioned categories, regardless of their reaching the age of 23 years old. According to M. Lazebna: "The situation regarding the provision of housing for orphans, children deprived of parental care, and the people from the above mentioned categories, remains critical and needs to be addressed immediately." As at January 1, 2019, the number of orphans and children deprived of parental care, including after reaching the age of 23 who were entitled to housing on a priority basis, amounted to 28,708 people, as at January 1, 2020, their number has already increased to 30,684 people. In particular, M. Lazebna informed the audience that in foster families, orphanages of family type, people from among orphans and children deprived of parental care with disabilities, who will become 18 years old, in particular, in 2020 - 23 people, 2021 - 29 people. However, the persons with disabilities who cannot study due to their health state are deprived of support from the state, still living in adoption families (unlike those who above 18 years old and who continue their studies) [10].

Ukraine has a considerable array of normative acts concerning the issues of children's social protection (the Family Code, the Child Welfare Law, the Education Law, the Act on Home Violence Prevention and etc.). The National Strategy for Reforming the Institutional Care and Upbringing of Children for 2017-2026, approved by the Cabinet of Ministers of Ukraine on August 9, 2017, is intended to promote the construction of the system of protection of children's rights under the new principles. Among other things, the document lays the foundations for applying the assessment as one of the key points for achieving the goals set in the Strategy [7]. However, considering the modern environment, it is sensible to conclude that Ukraine is unable to independently provide all the adequate social care conditions for their children. For which reason a 
number of international foundations and programs are being launched.

Conclusions.Having analyzed the historical aspects of children's social security in European countries from 17th century up until now. It has been concluded that throughout this period there have been a number of considerable changes in terms of child protection. In the context of this research, it has been highlighted that children's social security in Europe is characterized by providing assistance to them in order to facilitate the best conditions, which, in turn, exercise their rights and liberties. Another important aspect is creating various charitable institutions, schools, penitentiaries, which prompted children to change, as well as the emergence of social services to protect children's rights and interests. We have defined that children rights protection, altering their living conditions are the main prerequisite for their social lives as well as the main concern of any conscious adult citizen irrespective of the sphere. By infringing children's rights today we doom them for complications in the future, simultaneously depriving ourselves of the hope for support, understanding, respect and stability.

Received: 22.06.21

\section{ДЕРЖАВНА ПОЛІТИКА СОЦІАЛЬНОГО ЗАХИСТУ ДІТЕЙ ЯК ЧИННИК СОЦАЛЬНОЇ БЕЗПЕКИ: ІСТОРИЧНИЙ ДОСВІД СВРОПЕЙСЬКИХ КРАЇН 17-21 СТОЛІТТЯ}

Сургова $\boldsymbol{C}$. Ю., канд. пед. наук, доцент, Інститут державного управління, Чорноморський національний університет імені Петра Могили, м. Миколаїв, Україна

Файчук О. Л., канд. пед. наук, доцент, Інститут державного управління, Чорноморський національний університет імені Петра Могили, м. Миколаїв, Україна

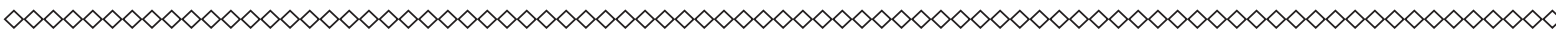

У статті розглядається історичний аспект розвитку державної політики соціального захисту дітей в країнах Європи 767 DOI: 10.34132/pard2021.13.09 
XVII - XXI cm. Мета статті полягає у висвітленні особливостей історичного розвитку державної політики соціального захисту дітей у європейських краӥнах XVII - XXI cm. та запозичення досвіду соиіального захисту дітей у контексті євроінтеграції Украӥни. В основу методології дослідження покладено приничип пріоритету загальнолюдських иінностей. У складі інструментарію запропонованої роботи теоретичний - аналіз та узагальнення психологічної та наукової літератури, навчально-методичні публікації на тему, синтез; порівняння та узагальнення даних. Автори припускають, що у ході вивчення історії питання державної політики сочіального захисту дітей, виникає можливість для проведення аналогій, здійснення вже перевірених історією кроків на иляху демократизації національної політики соціального захисту.

Ключові слова: державна політика, сочіальний захист населення, сочіальних захист дітей, історичний розвиток, діти з особливими потребами, безпритульні діти, Омбудсман у справах,інституичійний догляд.

\section{References}

1. Deklaratsiia prav dytyny vid 20 lystopada 1959 r. Rezoliutsiia 1386 (KhIV) Heneralnoi Asamblei OON vid 20 lystopada 1959 r. [Child's Rights Declaration from 20 November 1959.1386 Resolution (XIV) by UN General Assembly from 20 November 1959]. (n.d.). www.zakon.rada.gov.ua. Retrieved from: http://www.zakon.rada.gov.ua [in Ukrainian].

2. Dakal, A. (2016). Public policy on children's rights: the principles, objectives and means of implementing. Public administration mechanisms, 3, (pp. 59-65) [in Ukrainian].

3. Dity, zhinky ta simia v Ukraini: statystychnyi zbirnyk [Children, women and the family in Ukraine: a statistical collection]. (2020). (n.d.). www.ukrstat.gov.ua. Retrieved from: http:/www.ukrstat.gov.ua/druk/publicat/ kat_u/2020/zb/09/DJS_2019_pdf.pdf. [in Ukrainian].

4. Dubinskii, S.A. (1996). Sotsialnyiy trud v Germanii [Social Labor in Germany]. Moscow: State Academy of Consumer Goods and Services [in Russian]. 
5. Fan, S., Pang, Y. \& Pestieau, P. (2021). Investment in children, social security, and intragenerational risk sharing. Int Tax Public Finance. Retrieved from https://doi.org/10.1007/s10797-021-09664-3 [in English].

6. Kapska, A.I. (2009). Sotsialna pedahohiia [Social pedagogy]. Kyiv: Scientific literature center. [in Ukrainian].

7. Kontseptsiia realizatsii derzhavnoi polityky shchodo sotsialnoho zakhystu naselennia ta zakhystu prav ditei. (2020). (n.d.). zakon.rada. gov.ua. Retrieved from https://zakon.rada.gov.ua/laws/show/1057-2020$\% \mathrm{D} 1 \% 80 \#$ Text [in Ukrainian].

8. Korniushyna, R.V. (2004). Zarubezhnyiy opyit sotsialnoy rabotyi [Foreign experience in social work]. Vladivostok: Far East University [in Russian].

9. Kuzmin, K.V., \& Sutyrin, B.A. (2002). Istoriya obschestvennoy deyatelnosti $v$ zarubezhnyih stranah $i v$ Rossii s drevneyshih vremen do nachala 20 veka [History of social activity in foreign countries and in Russia since ancient times till early 20th century]. Moscow: Academic project [in Russian].

10. Lazebna, M. (2020). Minsotspolityky pratsiuie nad polipshenniam sotsialnoho zakhystu ditei-syrit i ditei, pozbavlenykh batkivskoho pikluvannia, yaki maiut invalidnist [The Ministry of Social Policy is working to improve the social protection of orphans and children deprived of parental care who have disabilities]. (n.d.). www.msp.gov.ua. Retrieved from: https://www.msp.gov.ua/ news/18836.html [in Ukrainian].

11. Palagnyuk, Yu., Pysmychenko O. (2018). Osoblyvosti rozvytku sotsialnykh posluh u systemi sotsialnoi polityky Nimechchyny [Features of the development of social services in the social policy system of Germany]. Teoriia ta praktyka derzhavnoho upravlinnia $i$ mistsevoho samovriaduvannia: elektr. nauk. fakh. vyd. Khersonskoho natsionalnoho tekhnichnoho universytetu - Theory and practice of public administration and local self-government: electronic scientific professional publication of Kherson National Technical University, 1, (pp. 7-8). [in Ukrainian].

12. Palchiebskii, S.S. (2007). Pedahohika [Pedagogics]. Kyiv: Karavela. [in Ukrainian].

13. Schweinitz, K. (1961). England's road Social Security. New York: A. S. Barnes \& Co. [in English].

14. Zakrynytska, V.O. (2012). Zarubizhnyi dosvid sotsialnoho zabezpechennia simi, ditei ta molodi: spetsyfika orhanizatsii ta pravovi normy [Foreign 
State policy of social protection of children as a social safety factor: historical experience of european countries from the 17 th to 21 th centuries

experience in social security of family, children and youngsters: specifications of organization and legal norms]. Ukrainskyi yuryst - Ukrainian Lawyer, 4, (pp. 36-42) [in Ukrainian].

15. Zhukov, V.I. (Ed.). (1994). Sotsialnoe obespechenie v stranah Severnoy Evropyi [Social security in the countries of Northern Europe]. Moscow: MGSU. [in Russian].

\section{Відомості про авторів / Information about the Authors}

Сургова Світлана Юріївна: Чорноморський національний університет імені Петра Могили вул. 68 Десантників 10, Миколаїв, 54003, Україна.

Svitlana Surgova: Black Sea National University of Petro Mohyla: 68 Desantnykiv str. 10, Mykolaiv, 54003, Ukraine.

\section{ORCID.ORG/ 0000-0002-3840-2924}

\section{E-mail: surgova.svetlana@gmail.com}

Файчук Олена Леонідівна: Чорноморський національний університет імені Петра Могили вул. 68 Десантників 10, Миколаїв, 54003, Україна.

Olena Faichuk: Black Sea National University of Petro Mohyla: 68 Desantnykivstr. 10, Mykolaiv, 54003, Ukraine.

ORCID.ORG/ 0000-0002-6663-3287

\section{E-mail: e.l.fajchuk@ukr.net}

